\title{
A Pattern Of Rural Tourism In The Songkhla Lake Basin, Thailand
}

Prachyakorn Chaiyakot, Prince of Songkla University, Thailand

Parichart Visuthismajarn, Prince of Songkla University, Thailand

\begin{abstract}
This article aims to determine a pattern of rural tourism that harmonizes with the Songkhla Lake Basin (SLB) resources in southern Thailand. Data were collected through a field survey, focus group discussions involving tourism stakeholders, a snowball sampling technique with SLB experts, and questionnaires with 400 tourists. The study found that the SLB tourism resources are located in a mountain range, in the foothills, in the lowlands, on the coast, and on a lake. The tourism field consists of a natural way of life; belief in Buddhist doctrines and the presence of monks, natural beauty, and sacred objects; folklore plays; local traditional events; and archaeological and historical sites. Ecotourism, cultural tourism, archaeological tourism and historical tourism are the aspects of rural tourism that harmonize with components of the SLB resources.
\end{abstract}

Keywords: Songkhla Lake Basin SLB; Tourism Resources; Rural Tourism; Thailand Tourism

\section{INTRODUCTION}

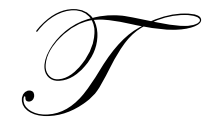

ourism is entering a changing era with respect to both tourist behaviors and how to present tourism to organizations worldwide. Today's tourists want to learn from personal experience, and get more experience from their travel. Alternatively, tourism, particularly rural tourism, has various tourism components to meet the needs of today's tourists because natural and cultural resources are located in rural areas and belong to the local people, including the area's atmosphere. Many rural areas have been developed to provide tourist activities suitable for education and relaxation. Rural tourism, which Knowd (1998, 8 quoted in EC-AEIDL, 1997) concluded is usually used to describe agri-tourism (tourism on farms) but also can encompass basically all tourism activities in the countryside. Rural tourism is a multi-faced activity (Ackar, 2006: 2837 quoted in Bramwell and Lane, 1994); it is not just farm-based tourism. It includes farm-based holidays but also comprises special interest nature holidays and ecotourism; walking, climbing, and riding holidays; adventure sports and health tourism; hunting and angling; educational travel; arts and heritage tourism; and, in some areas, ethnic tourism. Meanwhile, Rátz and Puczk (1998: 4 quoted in Gannon, 1988, in the Kloeze, 1994) stated that rural tourism includes a range of activities, services, and amenities provided by farmers and rural people to attract tourists to their area to generate extra income for their businesses. Rural areas (Arahi, 2008.) are not only the basis of agriculture and the place where rural people live but they are also national public property where people can relax and cultivate a calm and harmonious state of mind. Rural areas (Bandyopadhyay, 2003 quoted in Edgell \& Harbaugh, 1993) attract tourists because of their mystique and their distinct cultural, historic, ethnic, and geographic characteristics. Rural areas have great natural and cultural resources offering the multiple tourist activities and generating benefits for the local people. Tourists visit rural areas to learn about the culture and to experience folklore, customs, natural landscapes, and historical landmarks (MacDonald, 2003: 307).They might also enjoy other activities in a rural setting such as nature, adventure, sports, festivals, crafts, and general sightseeing. The forms of rural tourism in New Zealand (Hargreaves, 2002:3) include farm stays, ecotourism (to see birds and other wildlife), organic farming, adventure tourism, garden tours, horse trekking, skiing, rafting, and guided walks. Rural tourism conserves both natural resources and the way of life and traditional culture. In Thailand, rural tourism has great strength (Rattanasuwongchai, 2000:10) since it offers not only natural elements such as forests and mountains but also indigenous local characteristics such as traditions, customs, and folklore. 


\section{OBJECTIVE}

To identify a pattern of rural tourism that harmonizes with the Songkhla Lake Basin resources

\section{METHODOLOGY}

The area of this study, the Songkhla Lake Basin (SLB) (Ratanachai et al., 2005: 1-3) is located across three provinces of Southern Thailand, covering an area of 8,727 sq. km., approximately $150 \mathrm{~km}$. in length and $65 \mathrm{~km}$. wide. SLB has a population of around 1.6 million, with $69 \%$ living in rural areas and $31 \%$ in urban areas. However, the area to be studied for this research excludes the areas located in towns and municipalities. The study site is shown in Figure 1. A field survey and focus group discussion were conducted with central and local government organizations, tourism entrepreneurs, and community-based tourism networks in SLB. A snowball sampling technique was used with groups of academics, government officials, tourism entrepreneurs, and selected local people. 400 tourists visiting SLB tourist sites from March-June 2011 were questioned to determine the pattern of rural tourism in the SLB

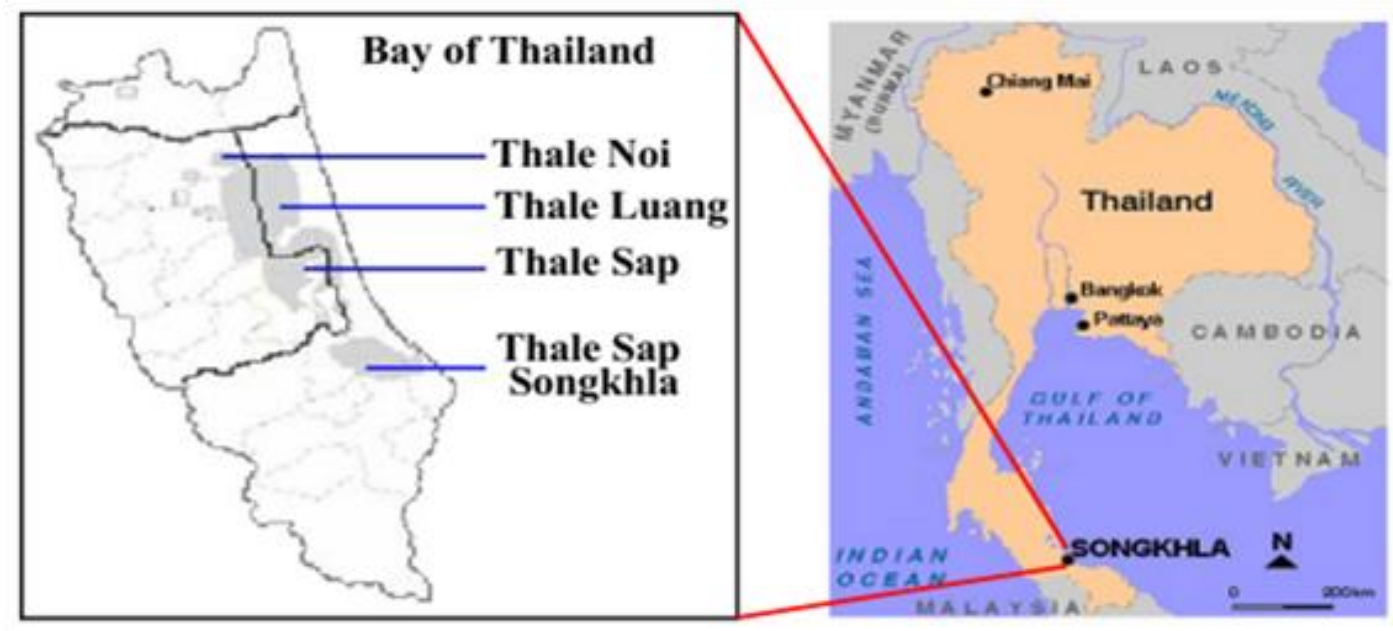

Figure 1: Map of Songkhla Lake

\section{RESULTS}

\section{The pattern of rural tourism in the SLB}

The tourism resources of SLB consist of natural and cultural resources and archaeological finds, especially Buddhist temples. They are located in a mountain range, in the foothills, in the lowlands, on the coast, and on a lake.

- Natural sites: mountains, waterfalls, a peat swamp forest, a wetland botanic garden, a national park, sanctuaries, non-hunting areas, a reservoir, hot springs, a mangrove swamp, canals, and a lake. The tourism activities include bird watching, long-tailed boating to see blooming lotuses, kayaking, biking, hiking, climbing, swimming learning about the lake's ecosystem, camping, and sightseeing.

- Cultural resources: way of life, belief in the Buddhist religion and mysteries, folk plays, and local traditional events:

- Way of life: adapted for tourism - rice farms, fruit farms, sugar palm gardens, fisheries, weaving, and carving. Tourist activities include growing and cultivating rice, collecting and tasting fruits, learning about plant species, simmering palm sugar, weaving, and carving.

- Beliefs: Buddhist doctrine, Buddhist monks' practices, ghost spirits, and sacred items in villages. Tourist activities include sprinkling holy water, offering robes for Buddhist monks, making and off- 
season offering of robes and other needs for monks, paying homage to Buddha, instructors' images and pagodas, and buying sacred items.

- Folklore plays: shadow plays, Manora dance (Southern dance), bullfighting, cockfighting, and dove contests.

- Traditional events: Magha Puja Day, Visakha Bucha Day, Songkran Festival, Chakphra Festival, presenting robes to monks at the end of Buddhist Lent, celebrations for dead Buddhist monks, the tenth lunar month festival, long tailed boat racing, drum beating festivals, boating, and bird watching festivals.

- Archaeological sites: Buddhist temples; standing, sitting, and reclining Buddha images; Buddhist pagodas, statues, instructors' images, folklore museums, old city walls, holy water-wells, and bridges. Tourist activities include learning about architecture and worshiping

- Historical sites: route of King Rama V, the history of Luang Por Tuad, people living on the Stingphra peninsula and the Thai gulf, and the Andaman sea trade route

The questionnaires were collected from 400 tourists who visited tourist sites in the SLB, and it was found that the top five objectives for traveling in SLB sites were as follows: 84 percent for recreation, 9 percent for educational tours, 4.8 percent to see relatives, 2.5 percent for meetings/training/seminars, and 1.8 percent to see new things. The top five tourist activities that tourists selected while travelling in the SLB - were as follows: 55 percent for ecotourism activities, 35.3 percent for cultural tourism activities, 33.0 percent for archaeological and historical tourism activities, 28.8 percent for shopping, and 27.3 percent for recreation tourism activities.

\section{CONCLUSION AND SUGGESTIONS}

The SLB is rich with natural and cultural resources and archaeological and historical sites. They are scattered across a mountain range, foothills, lowlands, the coast, and a lake. The tourist attractions in the SLB include natural and cultural features, way of life, belief in the Buddhist religion, Buddhist monks, sacred objects, and, local traditional events, and archaeological and historical sites. Because of the SLB's available resources, management, and tourist activities, ecotourism, cultural tourism, archaeological tourism, and historical tourism are obvious parts of the pattern of rural tourism that harmonize with components of SLB resources. However, many organizations, central and local government, foundations, private sector organizations, and local communities participate in managing these tourist attractions, and some tourist sites are controlled by many organizations duplicating both budgets and law enforcement. Some tourist sites are at risk of being destroyed by nature and invaders; thus, the existing SLB tourism resources must be protected by all stakeholders, not only in the tourism sector but also in other key sectors that use SLB resources, such as fisheries, agriculture, and industry. In terms of tourism development, a master plan for tourism development should be designed to bear tourism expansion in the future and rural tourism should be chosen as the first tool of tourism development. Local people should play an important role and participate in both tourism development and promotion. The goal of SLB tourism development should alleviate the poverty of the local people, reduce the invading public areas and deforestation, and involve all stakeholders. The integration of the tourism plans of all involved stakeholders will be very challenging for the development of SLB tourism.

\section{AUTHOR INFORMATION}

Mr. Prachyakorn Chaiyakot is a Ph.D. candidate, Faculty of Environmental Management, Prince of Songkla University, Hatyai, Songkhla, Thailand. He is a tourism management specialist. E-mail: prachyakornc@gmail.com. Corresponding author.

Dr. Parichart Visuthismajarn is an assistant professor at the Faculty of Environmental Management, Prince of Songkla University, Hatyai, Songkhla, Thailand. She is a risk management and ecotourism specialist. E-mail: parichart.v@psu.ac.th. 


\section{REFERENCES}

1. Akca, H. 2006. Assessment of rural tourism in Turkey using SWOT analysis. Journal of Applied Sciences 6 (13): $2837-2839$

2. Arahi, Y. 2008. Rural Tourism in Japan: the regeneration of rural communities. Retrieved on 6 August 2010 from, www.agnet.org/library/eb/457/eb457.pdf

3. Bandyopadhyay, R. 2003. Indian students' perception of rural West Bengal as a tourist destination. Ph.D. Candidate, School of Hotel, Restaurant and Recreation Management, The Pennsylvania State University. Retrieved on 3 September 2010 from, http://www.fs.fed.us/ne/newtown_square/publications/technical_reports/pdfs/2004/317papers/bandyopadhy ay317.pdf

4. Hargreaves, B. 2002. The Banks Peninsular Track-A Case Study in Rural Tourism. A Paper to be Presented to the Pacific Rim Real Estate Society Conference Christchurch, New Zealand, 21-23 January 2002.

Retrieved on 5 August 2011 from, http://www.prres.net/Papers/Hargreaves_The Banks_Peninsular_Track_Rural_Tourism.pdf

5. Knowd, I. 2001. Rural Tourism: Panacea and Paradox. Exploring the Phenomenon of Rural Tourism and Tourism's Interaction with Host Rural Communities. Retrieved on 6 August 2010 from, http://hsc.csu.edu.au/geography/activity/local/tourism/FRURALTO.pdf

6. MacDonald, R., and Jolliffe, L., 2003. Cultural rural tourism evidence from Canada. Annals of Tourism Research, 30 (2): 307-322

7. Ratanachai, C. 2005. Master Plan for Songkhla Lake Basin Development. Neo Point Press, Hat Yai, Thailand.

8. Rattanasuwongchai, N. 2000. Rural Tourism-the impact on rural communities II. Thailand

9. Rátz, T, L. Puczkó . 1998. Rural Tourism and Sustainable Development in Hungary; In: D. Hall - L. O'Hanlon eds.: "Rural Tourism Management: Sustainable Options" International Conference, Conference Proceedings; Scottish Agricultural College, Auchincruive, Ayr, Scotland, UK, pp.450-464. Retrieved on 6 August 2011 from, http://www.linkbc.ca/torc/downs1/Rural\%20Tourism\%20and\%20Development\%20in\%20Hungary.pdf 